\title{
AOIR
}

Selected Papers of \#AoIR2020:

The $21^{\text {st }}$ Annual Conference of the

Association of Internet Researchers

Virtual Event / 27-31 October 2020

\section{CHALLENGING SPATIAL MARGINALIZATION THROUGH SOCIAL MEDIA COMMUNICATION? A CASESTUDY OF THE TWITTER DISCOURSE ON HOUSING IN BERLIN}

\author{
Daniela Stoltenberg \\ Freie Universität Berlin, Institute of Media and Communication Studies

\section{Introduction}

Urban public life has historically and famously been structured by social stratification and a segregation of social milieus (Enos, 2017; Wirth, 1938). Such spatialized social inequality along the lines of, most importantly, class and ethnicity engenders unequal access to civic participation and supportive social networks (Kilroy, 2009). Recently, social media data have proven capable of revealing these phenomena of socio-spatial des-integration (e.g., Shelton et al., 2015).

Traditional, mass-mediated public discourses have largely been shown to reproduce socio-spatial inequality patterns. Local journalistic coverage focuses on places within the centers of cities while neglecting the periphery (Lindgren, 2009; Oliver \& Myers, 1999; Wiard \& Pereira, 2019). What focus there is on parts of the city outside the center is largely directed towards portraying districts with low socio-economic status and high shares of migrant populations in a negative light (Lindgren, 2009; Wiard \& Pereira, 2019).

Meanwhile, the Internet and Web 2.0 technologies in particular have often been hailed for their potential of bringing underrepresented voices into the public discourse and even creating so-called "networked counterpublics" (e.g., Jackson \& Foucault Welles, 2015), challenging social power structures.

This contribution seeks to address the question of whether social media communication about urban issues challenges or reproduces the unequal attention patterns that have been shown to emerge in the mass-mediated public spheres of segregated cities. To do so, it introduces the concept of issue spatiality by bringing together the understanding of

\footnotetext{
Suggested Citation (APA): Stoltenberg, D. (2020, October). Challenging Spatial Marginalization Through Social Media Communication? A Case Study of the Twitter Discourse on Housing in Berlin. Paper presented at AolR 2020: The 21th Annual Conference of the Association of Internet Researchers. Virtual Event: AolR. Retrieved from http://spir.aoir.org.
} 
issues as contentious, socially constructed matters of public debate (Miller \& Riechert, 2001) and an understanding of space itself as socially constructed (Löw, 2008). Issue spatiality then emerges through references to places in public communication (placenaming, see Wiard \& Pereira, 2019). Through place-naming, issues become associated with particular locations within a single urban context, which may direct political attention, and thereby ultimately aid in challenging or reproducing spatialized inequalities themselves.

Empirically, the contribution asks: In what ways is the representation of urban locations through place-naming in social media issue discourses distributed along the lines of spatialized social stratification?

\section{Method}

The study takes an issue- and location-centric understanding of public discourses. It is based on a dataset of 50,672 Twitter messages sent between December 2018 and April 2019 , discussing the issue of housing in Berlin and written by 18,274 unique users. Housing is a hot-button issue in the rapidly gentrifying city (Helbrecht, 2016), which has seen considerable political mobilization, both in the form of citywide popular referenda and hyperlocal tenants' initiatives. Berlin is also a pertinent case because it is among the most segregated German cities along the lines of class, ethnicity, and age (Helbig \& Jähnen, 2018).

To capture place-naming on a large scale, a simple computational approach was taken by applying a dictionary created for this purpose to the whole text corpus. Through this, references to locations within the cities were detected and subsequently mapped. In particular, textual references to the 96 districts of Berlin were searched. This yielded a final, location-based data set of 10,943 tweets by 5,474 unique users (21.6 percent of all messages), which referenced at least one district.

Regression analysis was leveraged to test whether population composition at the district level (share of elderly, share of non-citizen residents, average household income) as well as two issue relevance variables (average monthly rent, rent increase) explained the emergent attention distribution. Moreover, district population size and a dichotomous variable, which indicated whether the district shared a name with the larger administrative burrough, were included as controls.

\section{Results}

The analysis reveals a complex picture concerning the distribution of attention in the housing Twitter discourse across Berlin's urban space. The spread of attention across the 96 districts follows a power-law trajectory, with very few districts garnering the vast majority of attention, while most districts are barely visible in the discourse. Overall, a focus on the districts in the city center is clearly present, although there are some exceptions of districts even in the periphery receiving considerable discussion (see Figure 1). 

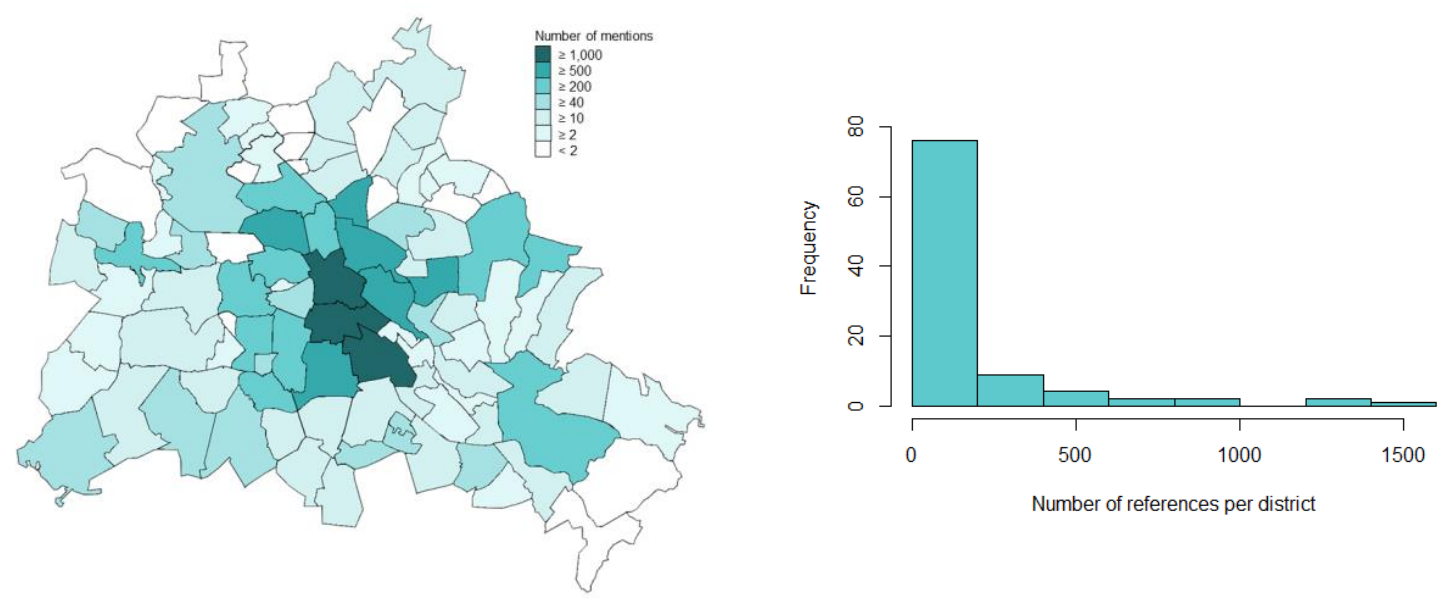

Figure 1: Number of mentions per district ( $N=50,671$ Tweets)

A negative binomial regression model (see Table 1) largely fails to explain the attention distribution. Unsurprisingly, the clearest predictor is district population size; that is, larger districts are discussed more frequently. The second powerful predictor is whether the districts name is also (part of) the name of the burrough (i.e., the next larger adminstrative unit), pointing to a challenge of disentangling location references by scale.

Neither the average household income nor the share of elderly residents in a district add significant explanatory value. Only the share of foreign citizens is significant, but surprisingly, the effect is a positive one (i.e., districts with more foreign citizens are mentioned more frequently). Moreover, two different markers for local issue relevance on the district level (average rent in new contracts, average rent increase between 2009 and 2017) also fail to explain variance.

Table 1: Negative binomial regression model for housing market Twitter discourse

\begin{tabular}{lrr} 
& $S E$ & $\operatorname{Exp}(B)$ \\
\hline (Constant) & 1.59 & 10.25 \\
Population (in 1,000) & $<.01$ & $1.02^{* * *}$ \\
Is Borough Name (binary) & .39 & $5.53^{\star * *}$ \\
Share of Elderly (65+) (in \%) & .03 & .97 \\
Share of Foreign Citizens (in \%) & .02 & $1.05^{*}$ \\
Household Income (in 1,000 €/month) & .34 & 1.06 \\
\hline Monthly Rent (2018, $€ / \mathrm{m}^{2}$, exc. utilities, new contracts) & .10 & 1.00 \\
Rent Increase (2009 to 2017) & .01 & 1.00 \\
\hline
\end{tabular}

\begin{tabular}{ll}
\hline Nagelkerke's Pseudo- $\mathrm{R}^{2}$ & .75 \\
\hline Dependent variable: & Number of references per Berlin district in $\mathrm{N}=10,943$ with at least one such \\
& reference \\
$\mathrm{n}=$ & 96 Berlin districts \\
Significance: & $*: p<.05 ;{ }^{* *}: p<.01 ;{ }^{* * *}: p<.001$ \\
Note: & $S E=$ standard error; $\operatorname{Exp}(B)=$ odds ratio
\end{tabular}




\section{Discussion and Outlook}

These results reveal an intriguing, if confusing picture of the issue spatiality of the housing discourse in Berlin's Twittersphere. Public discourse on this critical issue of urban life is clearly spatially structured, with a differential between center and periphery as the most striking pattern. This result is consistent with findings on the geographic attention distribution of local legacy media (Lindgren, 2009; Oliver \& Myers, 1999; Wiard \& Pereira, 2019). The regression analysis, however, suggests that neither sociodemographic nor issue characteristics at the district level are capable of explaining much variance. In a sense, this is a hopeful finding - segregation and sociodemographic disadvantage do not appear to determine the spatial distribution of attention on Twitter. On the other hand, many neighborhood populations are not represented in the discourse at all, even though they are not less affected by the overheated rental market.

It is noteworthy that this attention distribution still makes some intuitive sense to those familiar with Berlin and its political debates. One possible explanation for these patterns is that - rather than overall sociodemographic composition - the existence of a strong local civic culture and activist scene drives attention. Including aspects such as number of communit organizations or availability of neighborhood meeting places in future analyses could test this proposition.

Further analyses should also dive more deeply into the content of communication through a mix of automated and qualitative methods to tackle the question of whether different local narratives associated with spatialized power differentials exist within the Berlin housing discourse.

\section{References}

Enos, R. D. (2017). The Space Between Us. Social Geography and Politics. Cambridge: Cambridge University Press.

Helbig, M., \& Jähnen, S. (2018). Wie brüchig ist die soziale Architektur unserer Städte? Trends und Analysen der Segregation in 74 deutschen Städten (No. P 2018-001). WZB Discussion Paper.

Helbrecht, I. (Ed.). (2016). Gentrifizierung in Berlin: Verdrängungsprozesse und Bleibestrategien. transcript Verlag.

Jackson, S. J., \& Foucault Welles, B. (2015). Hijacking\# myNYPD: Social media dissent and networked counterpublics. Journal of Communication, 65(6), 932-952.

Lindgren, A. (2009). News, geography and disadvantage: Mapping newspaper coverage of high-needs neighbourhoods in Toronto, Canada. Canadian Journal of Urban Research, 18(1), 74-97. 
Löw, M. (2008). The constitution of space: The structuration of spaces through the simultaneity of effect and perception. European Journal of Social Theory, 11(1), 25-49.

Miller, M. M., \& Riechert, B. P. (2001). The spiral of opportunity and frame resonance: Mapping the issue cycle in news and public discourse. Framing public life: Perspectives on media and our understanding of the social world, 107-121.

Oliver, P. E., \& Myers, D. J. (1999). How events enter the public sphere: Conflict, location, and sponsorship in local newspaper coverage of public events. American journal of sociology, 105(1), 38-87.

Shelton, T., Poorthuis, A. \& Zook, M. (2015). Social media and the city: Rethinking urban socio-spatial inequality using user-generated geographic information. Landscape and Urban Planning, 142, 198-211.

Wiard, V., \& Pereira, F. H. (2019). Bad neighborhoods in a good city? Space, place and Brussels' online news. Journalism studies, 20(5), 649-674.

Wirth, L. (1938). Urbanism as a way of life. American Journal of Sociology, 44(1), 1-24. 